Original Research Paper

\title{
Himpunan Mahasiswa Pendidikan Fisika Mengabdi : Program Himafis Mengajar di Dusun Tojong-Ojong Sombek Desa Selebung Lombok Tengah
}

\author{
Rizky Munandar'1, Thufail Mujaddid Al-Qoyyim¹, Muhammad Abadi' ${ }^{1}$, W Wayan Gunada ${ }^{2}$ \\ ${ }^{1}$ Himpunan Mahasiswa Program Studi Pendidikan Fisika FKIP Universitas Mataram, Mataram, Indonesia \\ ${ }^{2}$ Dosen Pembina Himafis Program Studi Pendidikan Fisika FKIP Universitas Mataram, Mataram, Indonesia
}

https://doi.org/10.29303/jpmpi.v3i2.1247

Sitasi: Munandar, R., Al-Qoyyim, T. M., Abadi, M \& Gunada, I. W. (2021). Himpunan Mahasiswa Pendidikan Fisika Mengabdi : Program Himafis Mengajar di Dusun Tojong-Ojong Sombek Desa Selebung Lombok Tengah. Jurnal Pengabdian Magister Pendidikan IPA 4(4)

\author{
Article history \\ Received: 11 Nopember 2021 \\ Revised: 28 December 2021 \\ Accepted: 12 December 2021 \\ *Corresponding Author: Rizky \\ Munandar, Program Studi \\ Pendidikan Fisika FKIP \\ Universitas Mataram, Mataram, \\ Indonesia \\ Email: \\ rizkymunan03@gmail.com
}

\begin{abstract}
This activity aims to increase children's learning motivation during the pandemic through the play learning method. In addition, the Physics Education Student Association also carries out social activities such as community service and learning the Koran which is carried out at several points such as the Babussalam mosque which is located in the TojongOjong Sombek hamlet, Selebung Village. This activity also aims to analyze the potential of play learning methods in increasing children's interest in learning in the midst of a pandemic and provide training on physics concepts in water rocket games.
\end{abstract}

Keywords: Himafis Teaching Program, Physics Education

\section{Pendahuluan}

Mahasiswa harus bisa berbaur dengan masyarakat dalam menjalankan kewajibannya sebagai agen of change yang mampu menemukan solusi dari permasalahan yang ada di tengah masyarakat. Pengabdian adalah salah satu solusi yang bisa dilakukan untuk mengetahui permasalahan yang terjadi di tengah masyarakat. Berdasarkan UU No. 12 Tahun 2012, Pasal 1 Ayat 9 tentang Tridharma Perguruan Tinggi adalah kewajiban perguruan tinggi untuk menyelenggarakan pendidikan, penelitian, pengabdian kepada masyarakat, sehingga mahasiswa juga memiliki tanggung jawab yang sama untuk membantu menyelenggarakan tugas perguruan tinggi (Wibawa, 2017).

Mahasiswa juga harus memiliki rasa cinta tanah air melalui pengabdian yang mendorong tekad untuk membangun perubahan ditengah masyarakat. Inovasi dan kreativitas mahasiswa mampu menjadi salah satu pendorong untuk menciptakan solusi terbaru yang tentunya mampu mengembangkan
IPTEK. Ilmu pengetahuan adalah salah satu aspek yang berpengaruh di masyarakat. Dimana masyarakat harus memiliki pengetahuan sebagai dasar untuk meningkatkan kualitas masyarakat untuk pembangunan suatu bangsa. Sehingga berkembang menjadi sikap mental dan sikap hidup masyarakat yang mampu mendorong percepatan pembangunan di segala aspek kehidupan masyarakat untuk memperkukuh persatuan dan kesatuan (Lian, 2019).

Peranan mahasiswa dalam masyarakat bukan hanya sekedar untuk menemukan solusi dari permasalahan tetapi juga memiliki peranan akademik. Peran tersebut juga harus sejalan dengan tujuan pendidikan nasional tentang mencerdaskan kehidupan bangsa. Tujuan tersebut ialah sematamata untuk meningkatkan kualitas masyarakat dalam hal pengetahuan sebagai langkah awal pembangunan suatu bangsa. Sekaligus mendukung IPTEK sebagai kekuatan utama peningkatan kesejahteraan yang berkelanjutan dan peradaban bangsa. Peran tersebut menjadi nilai tambah bagi mahasiswa kepada masyarakat secara profesional dan proposional (Lian, 2019). 
Sebagai kaum intelektual dan anggota civitas akademik mahasiswa tentunya harus memiliki kemampuan serta inovasi dalam meningkatkan kualitas pendidikan. Kualitas tersebut berupa cara atau metode yang digunakan oleh mahasiswa dalam mengolah bidang ilmu supaya bisa tersampaikan kepada masyarakat (Cahyono, 2019). Pengolahan tersebut tentunya memiliki beberapa cara dan tahapan dalam mengolah pembelajaran yang tepat pada lingkungan masyarakat. Salah satu yang memiliki peranan dalam meningkatkan kualitas pendidikan adalah dengan menggunakan metode pembelajaran yang tepat. Metode pembelajaran bermain adalah salah satu metode pembelajaran yang tentunya bisa digunakan untuk meningkatkan minat belajar.

Pandemi covid -19 ini memiliki dampak besar bagi kalangan asyarakat maupun di dunia Pendidikan (Dolo dkk, 2021).Pada saat pandemi seperti saat ini tentunya minat belajar siswa mulai terganggu dengan diterapkannya sistem belajar dari rumah (online). Sistem tersebut selain menurunkan minat tetapi juga keaktifan siswa dalam belajar. Himpunan Mahasiswa Pendidikan Fisika (Himafis) mencoba menganalisis minat belajar siswa serta memberikan motivasi belajar dengan metode belajar bermain yang dilakukan di Dusun Tojong-Ojong Sombek Desa Selebung, Lombok Tengah. Metode pembelajaran tersebut dipilih karena memiliki kesesuaian dengan anak-anak disana yang mulai mengalami penurunan dalam minat belajar. Pendidikan yang seharusnya menjadi wadah untuk mengolah serta meningkatkan kualitas masyarakat justru menjadi permasalahan yang mulai kurang diminati oleh masyarakat, seperti banyaknya anakanak yang mulai enggan ke sekolah (Wulandari dkk, 2021).

Sehingga mahasiswa memiliki peranan untuk bisa mencaritahu solusi dari permasalahan tersebut. Mahasiswa juga harus memiliki kemampuan serta kompetensi dalam meningkatkan kualitas pendidikan. Standar kompetensi yang harus dimiliki oleh mahasiswa meliputi empat hal yaitu, pendagogik, kepribadian, profesional dan sosial. Kompetensi pendagogik antara seperti kemampuan dalam mengolah pembelajaran dengan meningkatkan pemahaman peserta didik, perancangan dan juga pelaksanaan yang siap dalam kegiatan pembelajaran. Kompetensi kepribadian meliputi tanggung jawab, kesiapan diri yang mantap, berwibawa serta mampu menjadi contoh bagi peserta didik maupun masyarakat (Gunada dkk,2021).

Kompetensi profesional adalah kemampuan dalam penguasaan materi, serta pengolahan diri yang siap serta berwawasan dalam menjalankan kewajiban dan peranan sebagai mahasiswa. Kompetensi sosial adalah kemampuan mahasiswa dalam berbaur pada masyarakat serta mampu menjalin hubungan baik sekaligus menjadi ide dan gagasan melalui inovasi dan kreativitas yang dimiliki oleh mahasiswa. Melalui kemampuan tersebut tentunya mahasiswa akan mampu meningaktkan kualitas pendidikan serta menjadi pedoman bagi masyarakat luas. Sehingga berdasarkan hal tersebut mahasiswa memiliki banyak peranan kepada masyarakat dan juga harus memiliki kemampuan lebih.

\section{Metode}

Metode yang digunakan dalam kegiatan Himafis Mengajar ini adalah metode observasi, ceramah, simulasi dan kerja praktik. Tahapan kegiatan ini, dilakukan dalam tujuh tahap selama tiga hari, yaitu:

\section{a. Tahap Pertama}

Hari pertama pelaksanaan Himafis Mengajar, dilakukan persiapan lokasi tempat melakukan kegiatan untuk tiga hari kedepan. Panitia dan peserta melakukan gotong royong area kegiatan akan berlangsung, panitia terbagi menjadi tiga kelompok untuk membersihkan lokasi. Para peserta juga ikut melakukan gotong royong. Ada yang menyapu area Bale Panggung ada juga yang menyapu bagian halaman atau bawah Bale Panggung. Panitia juga melakukan pemasangan spanduk.

\section{b. Tahap Kedua}

Pada tahap kedua, dilakukan pembukaan acara Himafis Mengajar secara formal. Kemudian dilanjutkan dengan kegiatan pertama yakni English fun, yang diawali dengan perkenalan dan Ice Breaking. Mentor yang dalam hal ini adalah panitia mengajarkan beberapa gerakan anak-anak dengan lagu bahasa inggris. Selanjutnya dilakukan pembagian kelompok yang terbagi menjadi tiga. Satu kelompok terdiri dari 6-8 peserta dan 3-4 panitia. Materi yang diberikan adalah greetings, pengenalan huruf abjad, dan warna-warna. Belajar sambil bermain dilakukan sekitar 20 menit. Selanjutnya semua kelompok kembali berkumpul 
pada ruangan, kemudian diadakan kuis-kuis yang berhadiah. Setelah kuis selesai, penutupan untuk hari pertama menyanyikan lagu abc dalam bahasa inggris. Pada malam hari, diadakan kegiatan mengaji bersama dengan panitia dan peserta.

\section{c. Tahap Ketiga}

Hari kedua pelaksanaan Himafis Mengajar, panitia dan peserta melakukan gotong royong area di sekitar lokasi. Panitia juga menyiapkan pembuatan taman baca untuk masyarakat Dusun Tojong Ojong Sombek.

\section{d. Tahap Keempat}

Kelas komputer adalah kegiatan selanjutnya, terdapat 11 kelompok yang setiap kelompok terdiri dari 2-4 anak yang didampingi oleh 1-2 mentor (panitia). Bahasan pada kelas komputer ini dilakukan bahasan dasar-dasar saja. Seperti cara menghidupkan dan mematikan laptop dengan benar, cara membuka word, cara mengatur kertas, cara membuat tabel, mengatur kertas, mengetik tulisan, mengatur huruf dll. Kemudian setelah belajar praktik komputer, diadakan kuis yang berhadiah.

\section{e. Tahap Kelima}

Kegiatan penutup pada hari kedua adalah Physics Fun. Setiap kelompok terdiri dari 4-6 orang peserta dan 2-3 panitia. Setiap kelompok membuat roket air dengan alat dan bahan yang telah disiapkan panitia sekitar 10-15 menit. Setelah roket semua kelompok sudah siap, roket tersebut dilombakan. Pemenang lomba dinilai berdasarkan kelompok yang roketnya jatuh pada tempat paling jauh, roket terbagus/ terapi, dan kelompok terheboh. Setelah lomba, adik-adik diberikan penjelasan ringan mengapa roket tersebut bisa terbang.

\section{f. Tahap Keenam}

Kegiatan pada hari terakhir adalah perlombaan, peserta dibagi menjadi empat kelompok dengan masing-masing terdiri dari 6-7 orang. Setiap kelompok didampingi masing-masing satu panitia. Games pertama adalah balap karung estapet. Selanjutnya games kedua yakni memasukan paku ke dalam botol.

\section{g. Tahap Ketujuh}

Pada acara penutupan ini juga dirangkaiakan dengan peresmian taman baca "LiterasiQu" oleh Kepala Dusun Tojong-Ojong Sombek dan Ketua Umum Himafis.

\section{Hasil dan Pembahasan}

Kegiatan Himafis Mengajar diikuti oleh 30 peserta (anak-anak) Dusun Tojong-Ojong Sombek dan 25 panitia Himpunan Mahasiswa Pendidikan Fisika Universitas Mataram. Bentuk kegiatan meliputi English Fun, Gotong Royong, Computers Course, Physic Fun dan Fun Games. Secara garis besar rangkaian kegiatan Himafi mengajar dapat dilihat pada Tabel 1 .

Tabel 1. Rangkaian Kegiatan Himafis Mengajar

\begin{tabular}{llll}
\hline No & Hari/Tanggal & & \multicolumn{1}{c}{ Kegiatan } \\
\hline 1 & Sabtu, 6 & - & English Fun \\
& Nopember & - & Mengajar Ngaji dan \\
& 2021 & & Kajian Islami \\
& & - & Gotong Royong \\
\hline 2 & Minggu, 7 & - & Computer Course \\
& Nopember & - & Physics Fun \\
& & - & Mengajar Ngaji dan \\
& & & Kajian Islami \\
& & - & Fun Games \\
& & Kegiatan Penutupan \\
& Senin, 8 & & \\
& Nopember & & \\
\hline
\end{tabular}

Kegiatan Himafis Mengajar dilakukan selama 3 hari dimulai pada tanggal 06-08 November 2021. Kegiatan ini juga memberikan wawasan kepada masyarakat mengenai beberapa hal seperti belajar bahasa inggris dasar, kursus komputer serta pembuatan alat permainan edukatif berupa roket air yang menjelaskan konsep fluida dan tekanan. Kegiatan ini juga mencoba meningkatkan motivasi belajar siswa dengan metode pembelajaran bermain sekaligus menganalisis potensi metode pembelajaran bermain untuk minat belajar. Masyarakat diberikan penjelasan mengenai roket yang dibuat yang dimana roket tersebut bisa meluncur karena adanya tekanan air yang memberikan gaya dorong.

Kegiatan Himafis Mengajar terdiri dari beberapa kegiatan inti yang menganalisis potensi metode pembelajaran bermain serta meningkatkan motivasi dan minat belajar. Mahasiswa menjadi wadah untuk mencoba menganalisis permasalahan dengan kegiatan tersebut sekaligus menjadi solusi pendidikan ditengah pandemi. kegiatan yang dilakukan antara lain seperti English Fun, Physics Fun, Computer Course, Fun Games dan Ngaji Bareng. 


\section{a. English Fun}

English Fun adalah satu kegiatan yang dilakukan dalam Himafis Mengajar, dimana anakanak diberikan materi dasar berbahasa inggris seperti Introduction, Greatting, Alphabet dan Colors. Pembelajaran tersebut menjadi semakin menarik karena dipadukan dengan Metode pembelajaran bermain, dimana anak-anak bernyanyi, bermain dan belajar bersama. Hasil yang diperoleh adalah meningkatnya minat belajar anakanak di Dusun Tojong-Ojong Sombek. Seperti yang diungkapkan Saleh \& Sugito (2015) mengungkapkan bahwa guru kelas hendaknya menciptakan suasana kelas yang kondusif yaitu suasana yang melibatkan anak-anak untuk dapat bermain bersama dengan teman lainnya sehingga nilai kelasnya akan lebih meningkat.

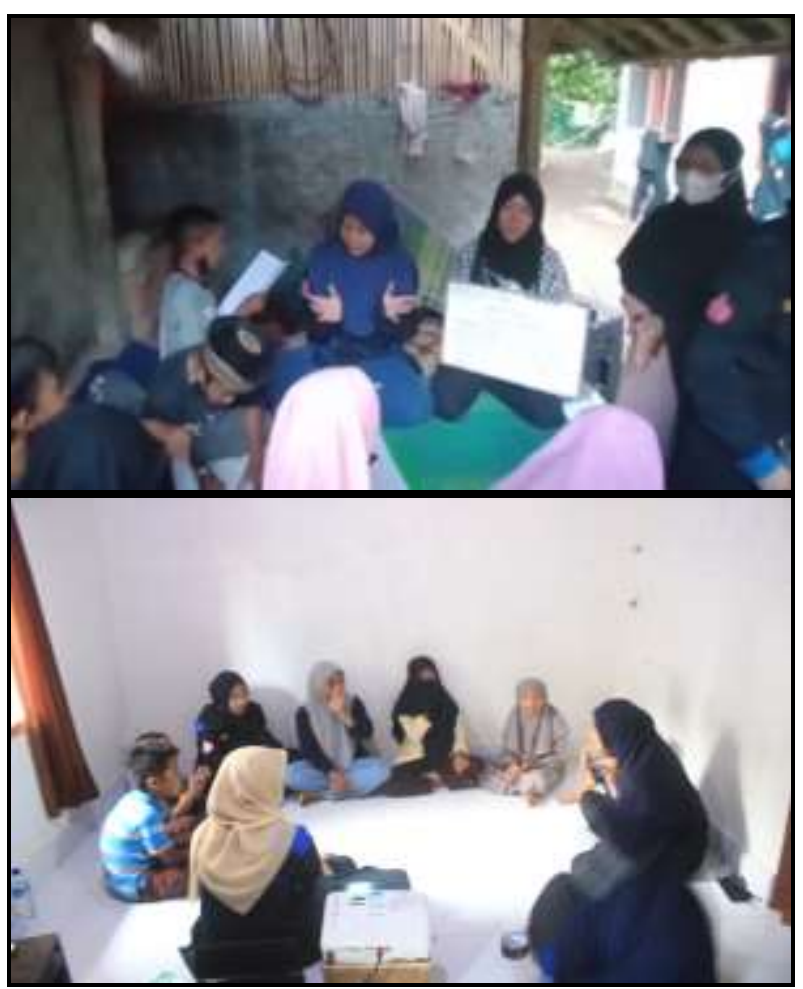

Gambar 1a dan 1b. Kegiatan English Fun

\section{b. Computers Course}

Kegiatan Computers Course dilakukan untuk melatih serta memberikan pengetahuan kepada anak-anak, seperti cara menghidupkan dan mematikan komputer, membuka microsoft word dan juga belajar menulis nama, tabel, menyimpan dan membuka file. Sekaligus memberikan wawasan mengenai microsoft, fungsi dan penggunaannya.

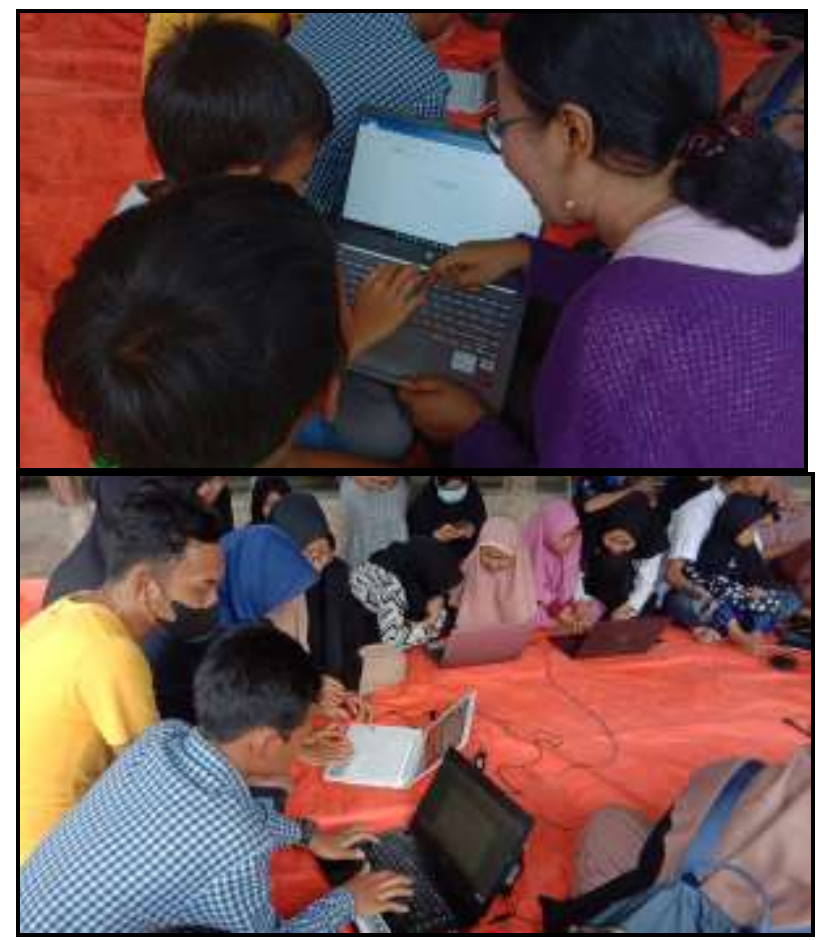

Gambar 2a dan 2b. Kegiatan Computers Course

\section{c. Physics Fun}

Physics Fun adalah salah satu kegiatan dalam Himafis mengajar yang dilakukan untuk bertujuan memberikan pemahaman mengenai ilmu fisika dengan metode pembelajaran bermain. Anakanak diberikan kesempatan untuk megetahui cara pembuatan roket air. Dimana pada permainan roket air dijelaskan mengenai konsep fluida dan tekanan dengan cara yang menyenangkan. Anak-anak ditunjukkan cara untuk merangkai roket air dan menjelaskan fungsi dari bagian roket air. Serta memberikan kesempatan kepada anak-anak dusun Tojong-Ojong Sombek untuk merangkai sendiri roket air yang mereka inginkan. Permainan yang mengasyikkan yang dipadukan dengan materi pembelajaran fisika akan meningkatkan daya tarik atau minat terhadap belajar sains khusunya ilmu fisika.

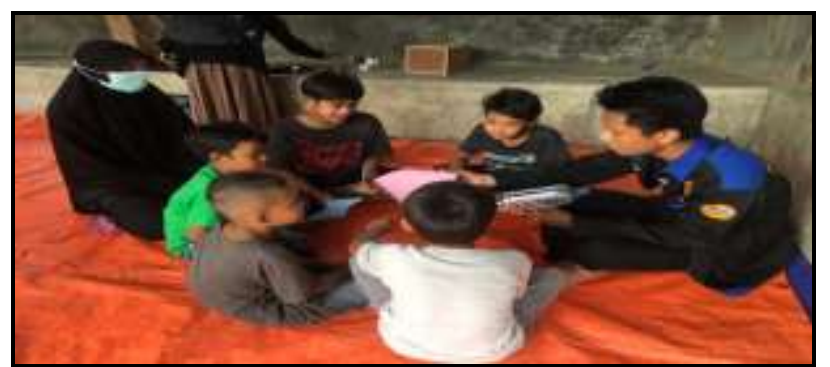




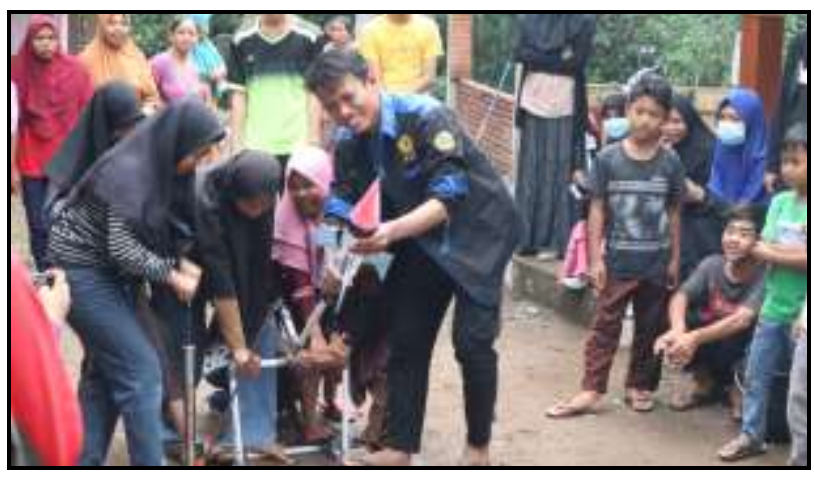

Gambar 3a dan 3b. Kegiatan Physics Fun

\section{d. Fun Games}

Pada kegiatan fun games anak-anak melakukan beberapa permainan seperti, balap karung estafet dan memasukkan paku ke dalam botol. Pada kegiatan ini anak-anak diharapkan mampu mencaritahu solusi dari permainan yang dipermainkan, sekaligus melatih kemampuan dan kekompakan pada setiap kelompok.

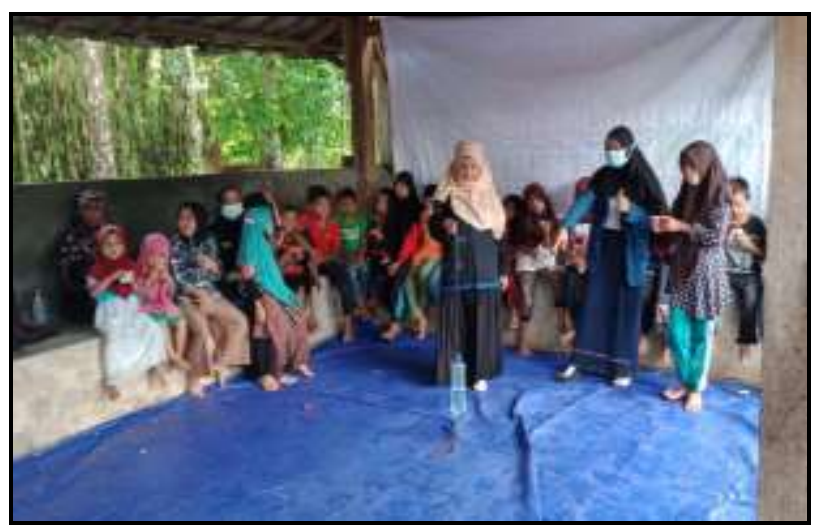

Gambar 4. Kegiatan Fun Games Anak Anak Perempuan

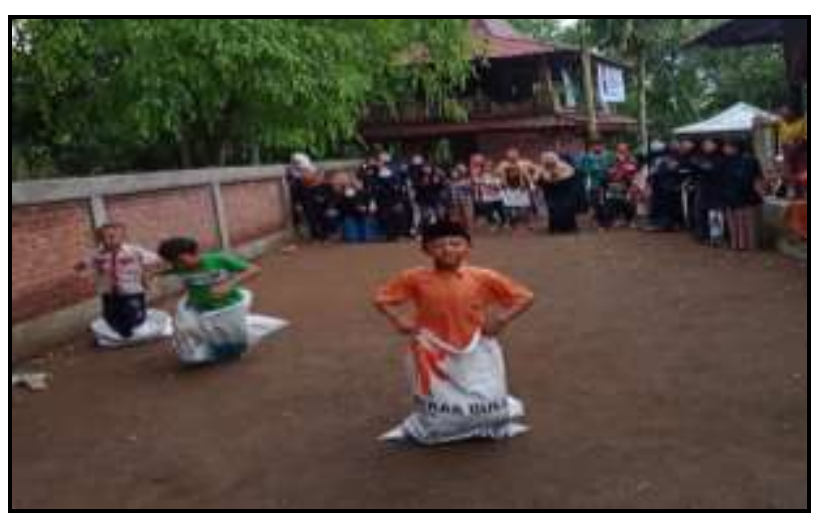

Gambar 5. Kegiatan Fun Games_Lari Karung

Berdasarkan kegiatan yang sudah dilakukan oleh Himpunan Mahasiswa Pendidikan Fisika FKIP
Unram dan kajian yang dilakukan pada saat proses ke lapangan, maka dapat dianalisis bahwa, metode pembelajaran bermain dapat meningkatkan minat dan motivasi belajar siswa pada saat pandemi Covid-19. Potensi tersebut dapat di lihat dari beberapa kegiatan yang melatih kekompakan serta pengetahuan anak-anak dalam hal belajar. Perpaduan antara ilmu pengetahuan dengan permainan sangat bagus dilakukan saat pandemi, selain melatih konsentrasi juga membantu menghilangkan rasa bosan anak-anak.

Cara himpunan mahasiswa pendidikan fisika untuk menjelaskan konsep fluida dan tekanan pada permainan roket air juga meningkatkan minat anak-anak. Hal tersebut bisa terlihat dari keaktifan anak-anak dalam proses pembuatan roket. Panitia menyiapkan bahan yang dibutuhkan, anak-anak menyusun sendiri dibantu oleh panitia sebagai pendamping yang memberikan arahan kepada anakanak dalam perakitan roket air sesuai dengan apa yang mereka inginkan. Keterlibatan anak-anak dalam proses pembuatan ini menjadi motivasi bagi anak-anak dalam kegiatan belajar ditengah pandemi saat ini.

Selain metode pembelajaran yang dibungkus dalam alat permainan edukatif, himpunan mahasiswa pendidikan fisika juga melatih anak-anak untuk lebih memiliki peran sosial kepada lingkunganya seperti membantu kegiatan gotong royong, melakukan Ngaji bersama, sekaligus meningkatkan keimanan lewat Kajian Islami. Kegiatan ini juga bagus untuk meningkatkan kepekaan sosial untuk anak-anak dusun TojongOjong Sombek yang rata-rata orang tuanya adalah petani. Anak-anak juga diharapkan mampu memanfaatkan lingkungannya untuk kegiatan belajar. Meningkatkan minat dan motivasi sekaligus menghilangkan rasa bosannya dalam kegiatan belajar online. Pendampingan kegiatan belajar dengan memanfaat lingkungan seperti barang bekas, di era covid 19 mampu meningkatkan minat dan kreativitas belajar (Jannah \& Pratiwi, 2021).

Kegiatan ini juga mendapat sambutan baik dari masyarakat. Baik dari tokoh masyarakat, tokoh agama dan orang tua anak-anak. Melalui kegiatan ini mereka berharap ada kegiatan berkelanjutan yang tentunya membantu anak-anak dalam kegiatan belajar. Selain itu dengan adanya kegiatan seperti ini anak-anak akan lebih aktif dalam mengembangkan kreatifitasnya. 
Kegiatan Himafis Mengajar juga membangun taman baca "LiterasiQu" yang diharapkan mampu dimanfaatkan dalam menunjang budaya literasi masyarakat dusun Tojong-Ojong Sombek. Karena dengan adanya taman baca merupakan salah satu solusi cerdas dalam meningkatkan minat baca (Syarif \& Elihami, 2020). Hasil kegiatan ini, diperkuat oleh hasil penelitian Widayati, dkk, (2021) menyatakan bahwa pengembangan literasi sains anak usia dini dapat dilakukan dengan memilih dan menggunakan alat permainan edukatif dalam bentuk konsep sains, proses sains, dan aplikatif sains. Hal ini secara langsung akan menumbuhkan kreativitas anak didik. Selain itu penghambat dalam kegiatan ini antara lain seperti waktu persiapan yang kurang dari pihak panitia/ pelaksana. Sehingga kegiatan yang dilakukan kurang maksimal. Kemudian kegiatan yang dilakukan pada musim penghujan juga menjadi salah satu faktor yang menghambat untuk dilakukannya kegiatan di luar ruangan.

\section{Kesimpulan}

Kegiatan Himafis mengajar dengan menerapkan metode pembelajaran bermain berbantuan alat permainan edukatif roket air, dapat meningkatkan minat dan motivasi belajar di tengah pandemic covid 19. Himpunan Mahasiswa Pendidikan Fisika juga mampu meningkatkan kreatifitas serta keterampilan yang dimiliki oleh anak-anak dusun Tojong-Ojong Sombek melalui pembuatan roket air sekaligus menjelaskan konsep fluida dan tekanan. Kegiatan yang dilakukan selama tiga hari ini juga mampu menjadi daya tarik bagi masyarakat sekitar. Sebagai tindak lanjut dari kegiatan, perlu diperhatiakan waktu pelaksanaan dan kegiatan lapangan sebaik mungkin sehingga kegiatannya lebih efisien.

\section{Ucapan Terima Kasih}

Penulis mengucapkan terima kasih yang sebesar-besarnya kepada Himpunan Mahasiswa Pendidikan Fisika, Dosen Pendidikan Fisika, dan segenap Pimpinan di lingkungan FKIP Universitas Mataram, Serta masyarakat khususnya anak-anak di Dusun Tojong-Ojong Sombek Desa Selebung yang telah memberikan dukungan dan kelancaran kegiatan Program Himafis Mengajar Tahun 2021.

\section{Daftar Pustaka}

Cahyono, H. 2019. Peran Mahasiswa Di Masyarakat. Jurnal Pengabdian Masyarakat Setiabudhi. (1), 1. 2686-6315: file:///C:/Users/ASUS/AppData/Local/Tem p/34-Article\%20Text-40-1-1020191218.pdf

Dolo, F. X., Kua, MY.,Nggia, SG., Pare, PJD., Jaghung, FP. 2021. Pendampingan Belajar Ipa Pada Masa Pandemi Covid-19 Berbasis Smart Solution Bagi Siswa Smp Di Desa Ratogesa. Jurnal Abdimas Ilmiah Citra Bakti. (2). 2. 2721-9178: https://doi.org/10.38048/jailcb.v2i2.400

Gunada, I. W., Sutrio, Wahyudi, Verawati, Busyairi, A. 2021. Pendampingan Kerja Praktik Untuk Meningkatkan Keterampilan Proses IPA Bagi Guru Guru SD Di Kota Mataram. Jurnal Pengabdian Magister Pendidikan IPA. (4), 4. 340-341: https://jppipa.unram.ac.id/index.php/jpmpi/ article/view/1137/830

Jannah, N. R., \& Pratiwi, E. 2021. Pendampingan Kegiatan Belajar Siswa dengan Memanfaatkan Barang Bekas untuk Meningkatkan Minat dan Kreativitas Belajar Siswa pada Era Covid-19. Bulletin of Community Engagement. (2), 1. 27747077:

https://attractivejournal.com/index.php/bce/ article/download/232/166

Lian, B. 2019. Tanggung Jawab Tridharma Perguruan Tinggi Menjawab Kebutuhan Masyarakat. Prosiding Seminar Nasional Pendidikan Program Pascasarjana Universitas PGRI Palembang 03 Mei 2019: file:///C:/Users/ASUS/AppData/Local/Tem p/2965-4891-1-PB.pdf diakses 2 Desember 2021.

Pitriana, P., Agustina, RD., Zakwandi,R., Ijharudin, M., Kurniawan, DT. 2018. Fun Science: Roket Air Sebagai Media Edu-Sains untuk Meningkatkan Motivasi Belaj ar Peserta Didik Sekolah Dasar. JIPFRI (Jurnal Inovasi Pendidikan Fisika dan Riset Ilmiah). (2), $1 . \quad$ 2549-9076: https://doi.org/10.30599/jipfri.v2i1.143.

Saleh, S. M., \& Sugito.2015. Implementasi Metode Bermain Peran Untuk Meningkatkan 
Kecerdasan Interpersonal Anak Usia 5-6 Tahun di TK Barunawati. Jurnal Pendidikan dan Pemberdayaan $\begin{array}{lll}\text { Masyarakat. } & \text { (2), } 1, & \text { 85-93: }\end{array}$ https://doi.org/10.21831/jppm.v2i1.4845

Syarif, A., \& Elihami, E. 2020. Pengadaan Taman Baca Dan Perpustakaan Keliling Sebagai Solusi Cerdas Dalam Meningkatkan Minat Baca Peserta Didik SDN 30 Parombean Kecamatan Curio. Maspul Journal Of Community Empowerment. (1), 1. 27164225: $\quad$ https://ummaspul.ejournal.id/pengabdian/article/download/548 1333

Widayati, J., R., Safrina, R., \& Supriyati, Y. 2021. Alat Permainan Edukatif: Analisis Perkembangan Literasi Sains Anak Usia Dini. (5) 1, 654-664: https://doi.org/10.31004/obsesi.v5i1.692

Wibawa, S. 2017. Tridharma Perguruan Tinggi (Pendidikan Dan Pengabdian Kepada Masyarakat). Ristek Dikti. Yogyakarta, 29 Maret 2017: https://unindra.ac.id/assets/uploads/file80.pdf

Wulandari, A., Hartawan, A., Syakir, M., Nursafitri, Natasya, N., Suwardi, RS., Paisal, S. 2021. Meningkatkan Minat Belajar Siswa di Masa Pandemi dengan Mengadakan Pembimbingan Kelas Belajar Anak Kelurahan Teppo Kecamatan Patampanua. Jurnal Lepa-lepa Open. (1), 2. 2776-4176: file:///C:/Users/ASUS/AppData/Local/Temp 17322-55479-1-PB.pdf 